\title{
Coping Strategies Among Brazilian Pregnant Women Living With HIV ${ }^{1}$
}

\author{
Evelise Rigoni de Faria ${ }^{2}$ \\ Grupo Hospitalar Conceição, Porto Alegre-RS, Brazil \\ Tonantzin Ribeiro Gonçalves \\ Universidade do Vale do Rio dos Sinos, São Leopoldo-RS, Brazil \\ Fernanda Torres de Carvalho \\ Secretaria de Saúde do Estado do Rio Grande do Sul, Porto Alegre-RS, Brazil \\ Rita de Cássia Sobreira Lopes \\ Cesar Augusto Piccinini \\ Universidade Federal do Rio Grande do Sul, Porto Alegre-RS, Brazil
}

\begin{abstract}
Pregnant women living with HIV (PWLH) face tremendous challenges in order to prevent their babies' infection. Coping is a potential buffer against negative outcomes from these challenges. This study aims to describe coping strategies of PWLH. This cross-sectional survey involved 77 PWLH from a public health care center in Brazil. Coping was measured for three types of strategies: Problem-focused, Emotion-focused, and Relationship support. Multivariate analyses identified some coping predictors. Being employed, reporting religious practice and higher CD4/immunity were associated with Problem-focused coping. Lower educational level was associated with Emotion-focused strategies. Relationship support strategies were more likely to be reported by PWLH who had good social support, who had disclosed HIV status to the baby's father, and who knew their infection before pregnancy. Findings underline the need for HIV interventions focused on social support and participation by the baby's father, with particular attention to those PWLH who were recently diagnosed and economically vulnerable.
\end{abstract}

Keywords: coping behavior, human immunodeficiency virus, pregnancy

\section{Estratégias de Enfrentamento de Gestantes Brasileiras Vivendo com HIV}

Resumo: Gestantes HIV-positivo vivenciam grandes desafios na prevenção da infecção de seus bebês, sendo as estratégias de enfrentamento possíveis facilitadores desse processo. Este estudo transversal objetivou identificar estratégias de enfrentamento de 77 gestantes HIV-positivo inseridas em um serviço de saúde pública do Brasil. Enfrentamento foi avaliado considerandose três fatores: Foco no Problema, Foco na Emoção e Foco na Busca de Apoio Social. Análises multivariadas identificaram preditores dessas estratégias. Emprego, prática religiosa e melhores exames de CD4/imunidade foram associados a estratégias focadas no Problema. Menor escolaridade associou-se a estratégias focadas na Emoção. Busca de Apoio Social esteve associada à disponibilidade deste apoio, à revelação do HIV ao pai do bebê e ao conhecimento do diagnóstico antes da gestação. Achados reforçam necessidade de intervenções voltadas ao apoio social e à participação do pai do bebê no atendimento de gestantes HIV-positivo, com especial atenção àquelas gestantes com diagnóstico recente e vulneráveis economicamente.

Palavras-chave: enfrentamento, HIV, gravidez

\section{Estrategias de Enfrentamiento de Mujeres Brasileñas Embarazadas que Viven con VIH}

\begin{abstract}
Resumen: Embarazadas VIH-positivo experimentan desafíos en la prevención de la infección del bebés, y las estrategias del enfrentamiento son facilitadores de este proceso. El objetivo del estudio transversal es describir las estrategias de enfrentamiento del 77 embarazadas VIH-positivo en un servicio de salud Brasileño. Se evaluó las estrategias centradas en lo Problema, en la Emoción, y en la Búsqueda del Apoyo Social. Análisis multivariado identificaron predictores de estas estrategias. Empleo, práctica religiosa y mejor CD4/imunidade se asocian con estrategias centradas en lo problema, y menos educación, con estrategias centradas en la emoción. Búsqueda del apoyo social se asoció con disponibilidad del apoyo, revelación del VIH para el padre del bebé y conocimiento del diagnóstico antes del embarazo. Intervenciones dirigidas para el apoyo social y la participación del padre del bebé al cuidado de estas madres se hacen necesarias, con especial atención a las embarazadas con diagnóstico reciente y en desvantaja económica.
\end{abstract}

Palabras clave: enfrentamento, VIH, embarazo

Globally, persons living with HIV face challenges in the same four domains: maintaining physical and mental

\footnotetext{
1 Acknowledgment: Serviço de Infectologia do Grupo Hospitalar Conceição, and Mary Jane Rotheram-Borus.

Support: National Council for Scientific and Technological Development (CNPq).

${ }^{2}$ Correspondence address:

Evelise Rigoni de Faria. Rua Ramiro Barcelos, 2600, sala 111. Santa Cecília. CEP: 90035-003. Porto Alegre-RS, Brazil. E-mail: everigoni@gmail.com
}

health, stopping transmission, and managing social relations - especially stigmatizing interactions around disclosure (Li, Lee, Thammawijaya, Jiraphongsa, \& Rotheram-Borus, 2009; Natividade \& Camargo, 2011). These aspects are expressed differently in each cultural context and each stage of human development. For example, pregnant women need to manage their own health and treatment in order to prevent transmission of infection to their babies, which involves a demand that is often experienced as stressful. 
However, coping skills can act as a potential buffer against negative outcomes that arise in the effort to deal with these challenges. Thus, our goal is to describe the coping strategies of pregnant women living with HIV (PWLH).

Heterosexual transmission of HIV has increased substantially in Brazil, especially in the low-income segment of the population. More than $90 \%$ of HIV cases among women are heterosexually acquired and around 200,000 women aged 15-49 years are living with HIV (Boletim Epidemiológico AIDS e DST, 2010-2011). Annually, about 12,000 women living with HIV give birth, representing an estimated HIV prevalence of $.4 \%$ in this population (Ministério da Saúde, 2010).

Brazil has been a global leader in providing universal access to HIV testing, medication and care since the early 1990s. Consequently, HIV mortality rate has dropped dramatically, and quality of life among Brazilian adults living with HIV has improved (Boletim Epidemiológico AIDS e DST, 2010-2011). Government initiatives to expand access to preventive treatment of mother-to-child transmission of HIV have contributed to timely diagnosis and counseling of PWLH. The Brazilian preventive treatment model includes: encouraging HIV testing, prenatal care and HIV treatment in a single point of care, antepartum antiretroviral therapy and intrapartum zidovudine, elective cesarean section, zidovudine and formula feeding for the newborn. However, less than $60 \%$ of estimated PWLH receive intrapartum zidovudine, with the lowest levels of treatment occurring among impoverished women. Access to quality HIV testing, counseling and health care remains a major concern (Boletim Epidemiológico AIDS e DST, 2010-2011; Ministério da Saúde, 2010).

Moreover, the stage of human development influences how PWLH face the four HIV challenges. They need to adopt an excellent adherence behavior, crucial to prevent HIV transmission to their babies. PWLH also feel guilt and anxiety about the possible negative impact of HIV on their children, such as child infection or their own death (D'Auria, Christian, \& Miles, 2006). In addition, PWLH worry intensely about situations that can disclose their HIV status, like not breastfeeding (Gonçalves, 2011). In order to avoid HIV disclosure, women often assume the exclusive responsibility for neonatal care and their newborn's medication (D'Auria et al., 2006; Faria \& Piccinini, 2010; Gonçalves \& Piccinini, 2008).

The way PWLH cope with these challenges can be decisive for their own mental health and their children's development. Many studies have investigated coping strategies and adjustment to chronic illness, built on Lazarus and Folkman's (1984) stress and coping model. This model considers coping as a central mediator in the adjustment process to stressful situations. Coping strategies are described as cognitive and behavioral efforts made to master, tolerate, or reduce external and internal demands that are perceived as exceeding one's current skills or resources. The authors identified two main coping strategies: Problem-focused coping, which involves problem solving or direct actions to alter the stressful situation, and Emotion-focused coping, which involves managing the emotional distress caused by the situation. Studies on coping usually refer to Problem-focused strategies as 'active coping', and to Emotional-focused strategies as 'passive coping'. It is generally accepted that Problem-focused coping prevails when individuals feel that they are in control of a situation, whereas Emotion-focused coping is more usual when individuals feel a situation is out of their control. A literature review identified a third type of coping strategy, characterized by seeking relationship support to deal with the stressful situation. Although it can be considered an active coping strategy, it differs from Problemfocused strategies in that it leads to the involvement of other people, with the coping occurring at a relational level (Seidl, Tróccoli, \& Zannon, 2001).

Coping strategies are important predictors of well-being in people with chronic diseases, and the stress and coping model for adjustment to HIV has been investigated and supported in other studies. Findings suggested associations between Emotion-focused coping and distress, and between Problem-focused coping and well-being in different samples of HIV-positive persons, such as adults (Friedland, Renwick, \& McColl, 1996), men who have sex with men (Pakenham \& Rinaldis, 2001), and parents living with HIV (Leslie, Stein, \& Rotheram-Borus, 2002). Studies also report the crucial role of social support for coping with HIV, which is associated with higher levels of Problem-focused coping (Leslie et al., 2002) and quality of life (Friedland et al., 1996).

Research with HIV-positive women has shown similar associations between coping styles and adjustment to disease. Moneyham et al. (1998) found that active coping was protective among HIV-positive women, and passive strategies were associated with poor overall adjustment, increased depression, and greater functional impairment. Rose and Clark-Alexander (1996) reported that the HIVpositive women in their study used more Problem-focused coping strategies, especially those women who had better physical health. On the other hand, Bennetts et al. (1999) evaluated Thai HIV-positive women during postpartum and found a high level of depressive symptoms associated with Emotion-focused coping.

Studies assessing coping strategies among Brazilian HIV-positive women, on the basis of a stress and coping model, are scarce. One Brazilian study (Seidl, Zannon, \& Tróccoli, 2005) reported greater use of Problem-focused strategies in comparison to other coping strategies among HIV-positive adults. However, women and people with low educational levels were more likely to use Emotionfocused coping in comparison to men and highly educated individuals. As observed in other countries, Emotion-focused coping was also associated with more negative outcomes among Brazilian adults living with HIV, such as low quality of life and depression.

In a study with Brazilian PWLH, increases in Problemfocused and Relationship support coping, and decreases in Emotion-focused coping were associated with improvements 
in quality of life during a psychoeducative intervention (Carvalho, 2009). Findings also indicated that women who had been living with diagnosed HIV for a longer period of time and women who had low educational levels reported more frequent use of Problem-focused strategies and less frequent use of Emotion-focused coping strategies, respectively.

Research on coping strategies indicates that, in the mid to long-term, Problem-focused coping is beneficial and Emotion-focused coping is often counterproductive. Brazilian women often discover their HIV diagnosis during prenatal care due to the facilitated access to HIV testing. Women then face a double demand: they need to deal with their own HIV infection and with motherhood. Thus, there is an urgent need for studies on coping among PWLH, as it is a population with high HIV prevalence levels in Brazil. Drawing on data from a survey conducted with Brazilian PWLH, this article describes the use of coping strategies in this group and their associations with demographic characteristics, social support, health status, HIV disclosure, and pregnancy variables.

\section{Method}

\section{Participants}

Seventy-seven pregnant women who were HIV-positive, aged 18 years or over, took part in this study. Exclusion criteria included current drug use, mental disorder, and severe physical disability. All participants were receiving the preventive treatment of mother-to-child HIV transmission, and were also attending the prenatal care in a public HIV health care center in Porto Alegre, Brazil.

\section{Instruments}

Coping strategies. The PWLH answered the Brazilian version of the Ways of Coping Checklist/WCCL (Seidl et al., 2001). This 45 -item scale requires the participant to focus on a current stressor. In the present study, we asked participants to focus on their HIV diagnosis. A previous study reporting on the result of a factor analysis, using a sample of 409 adults (Seidl et al., 2001), indicated the presence of four factors in the Brazilian version of this instrument (with Cronbach's alphas ranging between $.70-.84)$. The instrument includes questions about Problem-focused coping (18 items), Emotion-focused coping (15 items), Religious coping (7 items) and Relationship support coping (5 items). Participants rate their agreement with each of the statements on a 5-point Likert scale ranging from 1 (I never do that) to 5 (I always do that). Factor scores were the mean score based on the sum of ratings for each item in the factor. In this paper, analyses were concentrated on Problem-focused, Emotionfocused and Relationship support coping.

Demographic characteristics. Participants completed a structured interview to obtain demographic data, including age, educational level, number of children, marital status, employment status, financial support and religious practice.

Social support. The Brazilian adapted version of the Social Support Inventory for People who are HIV Positive or Have AIDS was used to measure social support (Seidl \& Tróccoli, 2006). This 24-item scale is used to assess three types of social support (instrumental, informational, emotional), and includes ratings of received support, satisfaction with support, and source of the support (Cronbach's alpha of .87). It is rated on a 5-point Likert scale and higher scores denote higher levels of social support. The types of social support were highly correlated in our sample $(p \leq .01)$. For this reason, we considered the overall social support score (mean score based on all items).

Health status, HIV disclosure and pregnancy variables. Participants completed a structured interview about health, HIV disclosure and pregnancy related information. They were asked about time since diagnosis and whether they disclosed or not their HIV status to baby's father and to their family. Other biomedical information (AIDS diagnosis, CD4 count, detectable/undetectable viral load) was obtained from participants' medical records. Regarding pregnancy information, participants were considered primiparous if they had never given birth before, including those who got pregnant but had a miscarriage in the past. They were also asked about gestational age, number of prenatal visits, and if they discovered the HIV diagnosis during current pregnancy.

\section{Procedure}

Data collection. A cross-sectional survey on coping strategies and associated predictors was conducted as part of a longitudinal study with PWLH (Piccinini et al., 2005). Between May 2006 and August 2008, all PWLH $(n=139)$ enrolled at the center were invited to participate in the longitudinal study. Twenty-seven women did not match the inclusion criteria. Twelve women could not be contacted again or withdrew from the study before completing the baseline assessment. There were no statistically significant differences in any sociodemographic characteristics between women who were included in the project and those who were not. Of the 90 PWLH included in the longitudinal project, 77 answered a scale on coping and were included in the present study. PWLH in the baseline sample are the focus of this paper.

Baseline assessments were conducted over two subsequent one-hour interviews. Instruments were administered in private settings by trained interviewers who were not clinical staff members. Participants received financial reimbursement for food and transportation to complete the interview (R\$25, equivalent to \$15 USD at the time of the study).

Data analysis. Statistical Package for the Social Sciences (SPSS, version 18, PASW) was used for statistical analysis. First, descriptive analyses were conducted. Second, bivariate analyses (two-tailed $t$ tests, Pearson correlation) were used to examine the relationships between each 
coping factor (Problem-focused, Emotion-focused, and Relationship support) and the other variables. Each variable was submitted to Kolmogorov-Smirnov test in order to verify the normal distribution. Those with deviations from normality were analyzed using non-parametric tests. Last, three multiple regression models were performed with the Problem-focused, Emotion-focused, and Relationship support coping scores. Variables significant at $p \leq .1$ for each factor in bivariate analyses were included in the final models.

\section{Ethical Considerations}

The longitudinal project received approval from the Ethics Committee at Universidade Federal do Rio Grande do Sul, Protocol 2005508, and informed consent was obtained for each participant.

\section{Results}

\section{Participant Characteristics}

All PWLH were in the third trimester of pregnancy, and the mean pregnancy time was 3.5 weeks $(S D=4.1)$. Most of them $(76.6 \%)$ were married, $83.1 \%$ had other children, with an average of 1.8 children $(S D=1.4)$. The mean age was 27.9 years $(S D=5.8)$, and the mean education was 7.5 years $(S D=3.1)$. Almost half $(45.5 \%)$ of the participants were employed and $39.0 \%$ were receiving financial support from relatives or governmental social programs. Around half of the PWLH (55.8\%) stated that they engaged in religious activities. Among those, 65\% were Catholic, 23\% were Protestant, and 12\% indicated other religions. All PWLH acquired HIV via heterosexual relationships. Most of the participants $(74.0 \%)$ were diagnosed before their current pregnancy, and 3.9 years $(S D=3.6)$ was the mean time of diagnosis. At the time of the study, nearly $65 \%$ of the women had AIDS (CD4 $\leq 350$ cells $/ \mathrm{ml}$ ), 49.4\% had undetectable viral load, the sample CD4 count mean was 422.6 (range $=50-1029)$, and no women referred current physical symptom related to HIV. The diagnosis was disclosed to the baby's father and to family members in $83.1 \%$ and $75.3 \%$ of the PWLH's cases, respectively. The mean social support score was $3.6(S D=.8$; range $=1-5)$. The mean number of prenatal visits was $5.2(S D=2.0)$. Only $18.2 \%$ reported drug use (e.g., crack/cocaine, alcohol, marijuana) at any time in life, but no longer at the time of the study.

\section{Coping Strategies Among PWLH}

Descriptive analysis shows that Problem-focused coping were the most common strategy among PWLH $(M=3.7 ; S D=.7 ;$ range $=1-5)$, followed by both Emotionfocused $(M=2.6 ; S D=.7)$ and Relationship support coping $(M=2.6 ; S D=.8)$. No strong correlations were found between the three coping factors, suggesting that they represent independent strategies as predicted in the Brazilian version of the scale (Seidl et al., 2001). Results of mean comparisons and correlations of coping strategies by demographic, social support, health information, HIV disclosure and pregnancy variables are summarized in Table 1. Low educational level was associated with higher reports of Emotional-focused

Table 1

Participant Characteristics and Coping Strategies $(N=77)$

\begin{tabular}{|c|c|c|c|}
\hline Variables & $\begin{array}{l}\text { Problem- } \\
\text { focused }\end{array}$ & $\begin{array}{l}\text { Emotion- } \\
\text { focused }\end{array}$ & $\begin{array}{c}\text { Relationship } \\
\text { support }\end{array}$ \\
\hline $\begin{array}{l}\text { Continuous } \\
\text { variables }\end{array}$ & \multicolumn{3}{|c|}{ Correlation Coefficients } \\
\hline Age & .123 & -.034 & -.134 \\
\hline Education (years) & .022 & $-.355 * *$ & .055 \\
\hline Number of children & -.087 & .137 & -.105 \\
\hline $\begin{array}{l}\text { HIV infection } \\
\text { diagnosis (years) }\end{array}$ & -.067 & -.113 & .095 \\
\hline CD4 cell count & $.216^{+}$ & .031 & .147 \\
\hline $\begin{array}{l}\text { Pregnancy time } \\
\text { (weeks) }\end{array}$ & .081 & .053 & -.194 \\
\hline $\begin{array}{l}\text { Number of } \\
\text { prenatal visits }\end{array}$ & .009 & -.156 & -.014 \\
\hline Social support & $.306 * *$ & -.129 & $.397 * *$ \\
\hline Categorical variables & & $M(S D)$ & \\
\hline \multicolumn{4}{|l|}{ Married } \\
\hline Yes & $3.7(0.7)$ & $2.6(0.7)$ & $2.7(0.8)^{*}$ \\
\hline No & $3.6(0.5)$ & $2.7(0.8)$ & $2.2(0.9)$ \\
\hline \multicolumn{4}{|l|}{ Employed } \\
\hline Yes & $3.9(0.8)^{* *}$ & $2.6(0.7)$ & $2.7(0.7)$ \\
\hline No & $3.5(0.5)$ & $2.7(0.5)$ & $2.5(1.0)$ \\
\hline \multicolumn{4}{|l|}{$\begin{array}{l}\text { Receiving financial/ } \\
\text { material support }\end{array}$} \\
\hline Yes & $3.6(0.9)$ & $2.7(0.6)$ & $2.4(1.0)$ \\
\hline No & $3.7(0.5)$ & $2.6(0.7)$ & $2.8(0.7)$ \\
\hline \multicolumn{4}{|l|}{ Religious practice } \\
\hline Yes & $3.9(0.8)^{*}$ & $2.6(0.7)$ & $2.6(0.8)$ \\
\hline No & $3.5(0.5)$ & $2.6(0.7)$ & $2.6(0.9)$ \\
\hline \multicolumn{4}{|l|}{ Primiparous } \\
\hline Yes & $3.7(0.6)$ & $2.3(0.8)$ & $2.4(0.9)$ \\
\hline No & $3.7(0.7)$ & $2.7(0.6)$ & $2.7(0.8)$ \\
\hline \multicolumn{4}{|l|}{$\begin{array}{l}\text { Diagnosed during } \\
\text { current pregnancy }\end{array}$} \\
\hline Yes & $3.7(0.6)$ & $2.7(0.5)$ & $2.3(0.7)^{+}$ \\
\hline No & $3.7(0.7)$ & $2.6(0.7)$ & $2.7(0.9)$ \\
\hline \multicolumn{4}{|l|}{$\begin{array}{l}\text { HIV disclosure to } \\
\text { baby's father }\end{array}$} \\
\hline Yes & $3.6(0.5)$ & $2.6(0.7)$ & $2.8(0.8)^{* *}$ \\
\hline No & $4.0(1.2)$ & $2.8(0.7)$ & $1.8(0.7)$ \\
\hline \multicolumn{4}{|l|}{$\begin{array}{l}\text { HIV disclosure to } \\
\text { family }\end{array}$} \\
\hline Yes & $3.7(0.7)$ & $2.6(0.7)$ & $2.7(0.8)$ \\
\hline No & $3.6(0.6)$ & $2.6(0.7)$ & $2.3(1.0)$ \\
\hline \multicolumn{4}{|l|}{$\begin{array}{l}\text { Undetectable viral } \\
\text { load }\end{array}$} \\
\hline Yes & $3.8(0.6)$ & $2.4(0.6)^{*}$ & $2.7(0.7)$ \\
\hline No & $3.6(0.8)$ & $2.8(0.7)$ & $2.6(0.9)$ \\
\hline
\end{tabular}


coping. Social support was positively associated with both Problem-focused and Relationship support coping strategies. PWLH who reported having a religious practice and those who were employed were more likely to use Problemfocused strategies. Participants who were married and who disclosed their HIV status to the baby's father reported higher means of Relationship support strategies. Yet, PWLH with higher viral load were more likely to use Emotional-focused coping. Time since diagnosis, being primiparous, pregnancy time, and number of prenatal care visits were not associated with coping strategies.

Results of multiple regressions are displayed in Table 2. PWLH who were employed, reported religious practice and had higher CD4 count were more likely to use Problemfocused strategies. Those with lower education tended toward using more Emotion-focused strategies. Finally, Relationship support coping strategies were more likely to be reported by PWLH with more social support, who reported disclosed HIV status to baby's father, and who knew their HIV status before pregnancy. The Chi-square test was performed to verify if being diagnosed with HIV during pregnancy would be associated with disclosure to baby's father. No associations were found $(p=.9)$, showing that these variables were independently associated with Relationship support coping.

Table 2

Multiple Regressions on Coping Strategies $(N=77)$

\begin{tabular}{|c|c|c|c|}
\hline & Problem-focused & Emotion-focused & Relationship support \\
\hline & & Standardized beta coe & \\
\hline Education (years) & & $-.305 * *$ & \\
\hline Married & & & .062 \\
\hline Employed & $.260 *$ & & \\
\hline Religious practice & $.310 * *$ & & \\
\hline Social support & .097 & & $.357 * *$ \\
\hline Undetectable viral load & & -.178 & \\
\hline Diagnosis in current pregnancy & & & $-.246^{*}$ \\
\hline CD4 cell count & $.292 *$ & & \\
\hline Disclosure to baby's father & & & $.335 * *$ \\
\hline $\mathrm{R}^{2}$ & .193 & .132 & .317 \\
\hline
\end{tabular}

\section{Discussion}

Although many studies have highlighted the importance of coping strategies for dealing with HIV, there is little information regarding coping during pregnancy concurrently to HIV. We found many associations between coping strategies and health status, demographic variables, social support, HIV disclosure, and moment of diagnosis among PWLH. In addition, descriptive analysis alerts to a particular situation: most of the PWLH had AIDS and already knew their HIV status before pregnancy. These findings reinforce the need for health providers to address the reproductive intentions of HIVpositive women during their regular HIV treatment. Timely counseling could help these women in getting pregnant in a safer and healthier context, which would contribute to reduce the mother-to-child transmission risk.

Despite the availability of treatment to prevent motherto-child transmission of HIV and the high number of prenatal visits among participants, in comparison with people in other developing countries (Zanconato, Msolomba, Guarenti, \& Franchi, 2006), only half of the PWLH had an undetectable viral load. A possible explanation may be low adherence both to their own HIV treatment before pregnancy and to preventive treatment of mother-to-child transmission among our sample, but further studies are necessary to clarify this situation. Supporting prior literature (Pakenham \& Rinaldis, 2001; Rose \& Clark-Alexander, 1996), Problem-focused strategies were found as a protective factor of the health status, due to the association with high CD4 cell count among participants. PWLH may benefit from using these coping strategies due to their direct impact on improving adherence to treatment and health maintenance.

Being employed and having higher educational level were associated with greater use of Problem-focused and less use of Emotion-focused strategies, suggesting that these PWLH were coping with HIV in a more successful way. Education and socioeconomic status have been associated with perceptions of personal control over HIV stressors among women (Kim, Pronyk, Barnett, \& Watts, 2008). In addition, less educated PWLH tend to be more vulnerable to psychological stressors, considering their need to manage financial and social restrictions (Carvalho, 2009). Our results match previous studies and reinforce the need for interventions addressing the social vulnerability behind psychological stressors in PWLH, focusing on economic empowerment (Kim et al., 2008).

Although only half of PWLH reported religious practice, these women were coping with HIV more actively. The importance of religiosity for coping with stressful situations has been highlighted in the literature (Rocha \& Fleck, 
2011). Our findings show that religiosity may be particularly important during pregnancy, when active coping strategies are crucial for adherence to preventive treatment of motherto-child transmission of HIV. However, we only considered self-report about engagement in religious practice, excluding specific information about the frequency of activities or degree of religious involvement. Further research is needed to determine the extent to which religiosity may contribute to coping among PWLH.

Perceived social support showed an important role among PWLH, given the positive association with Relationship support coping strategies. Probably, PWLH who perceived greater availability of social support were more likely to seek their social network in order to deal with infection. Moreover, these women also receive more information and emotional support, enabling them to actively coping with HIV (Kim et al., 2008; Leslie et al., 2002).

In our sample, there was a high rate of HIV disclosure to the baby's father, which was positively associated with Relationship support coping. Other studies indicate that the target of disclosure is usually one of the primary providers of social support (Rice, Comulada, Green, Arnold, \& RotheramBorus, 2009). Since the baby's father knows about the HIV status, he can provide support for dealing with HIV and the preventive treatment of mother-to-child transmission of HIV. In addition, the woman is more able to seek him as a source of support. We need to consider the crucial role of the baby's father during pregnancy, when men are more likely to be involved and emotionally connected with the baby and their partner (Silva \& Piccinini, 2007; Souza \& Benetti, 2009). In the HIV context, the father is probably also worried about the child's health and more willing to support the woman to follow the preventive treatment procedures. In addition, pregnancy seems to be a great opportunity for getting fathers involved in their own treatment or in preventive HIV interventions. Considering the high rates of HIV disclosure to the baby's father found in our sample, further studies are necessary to understand the role of the partner in different populations, for example, pregnant women who are not engaged in the prenatal care.

Although 'time since diagnosis' was not associated with coping, a significant association emerged when PWLH were classified, considering if they received the HIV diagnosis before or during current pregnancy. A noteworthy finding of the present study is that being diagnosed with HIV during pregnancy can impose difficulties to gather social support to cope with the infection. Literature has well documented the great emotional burden involved in receiving a HIV diagnosis, especially for the initial phase of adjustment to HIV and due to the HIV-related stigma (Psaros, Geller, \& Aaron, 2009). Our findings alert us to the need to address this particular group of women who received their diagnosis concurrently with confirmation of their pregnancy. These women need to assimilate their diagnosis faster in order to proceed with the preventive treatment of mother-to-child transmission of HIV. They also need to redirect previous expectations about motherhood experience, which is often a psychologically stressful process (D'Auria et al.,
2006; Faria \& Piccinini, 2010). Associations found between less Relationship support coping and being diagnosed with HIV during pregnancy raise other dimension in this complex situation: these women may be isolated, becoming even more vulnerable to distress. Many women discover their HIV diagnosis during prenatal care, particularly in Brazil where HIV testing is encouraged as part of preventive treatment of motherto-child transmission of HIV (Ministério da Saúde, 2010). Our results alert about the urgency for interventions targeting this particular group of PWLH.

Surprisingly, other variables related to pregnancy (e.g. gestational age, being primiparous) did not show important associations with coping. Some possible explanations are presented. Even though PWLH vary in terms of gestational age, all of them were in the third trimester, when the initial ambivalence related to pregnancy tends to be overcome, the baby becomes more real, and the childbirth is approaching (Stern, 1998). Considering this pregnancy stage, the small time differences were not sensitive enough to identify associations with coping strategies. Similarly, being primiparous did not influence coping strategies among our participants. Literature emphasizes that first-time mothers face specific challenges in adapting to the new identity recognized in the maternal role (Stern, 1998). For PWLH, the psychological and social adjustments during the transition to motherhood happen at the same time as they need to cope with HIV, which could exacerbate their emotional burden and affect their coping strategies. Nevertheless, our findings did not support this hypothesis. Actually, the moment of discovering the HIV diagnosis (e.g. prior to or during their current pregnancy) seems to have a stronger influence on coping with HIV than being primiparous or not, and is be an important variable to be considered when health interventions are designed.

\section{Conclusions}

This study offers an important contribution by focusing on coping with HIV during pregnancy, considered a developmental period with specific challenges associated both to motherhood and to HIV diagnosis, and whose population of PWLH is still little studied in the literature. However, some limitations need to be considered. Because this was a cross-sectional survey conducted in a relatively small sample, we are cautious about the possibility of generalizing these results. Additionally, this study was conducted using a clinic-based convenience sample, which may not represent community samples. Furthermore, other psychological measures were not assessed (e.g. depression, self-esteem), and it could be responsible for part of the unexplained variance in coping regression models.

Despite the limitations, this study offers important contributions for clinical practice in the health field. Findings underline the need for interventions that emphasize social support, promote the baby's father participation, and give particular attention to those PWLH who were recently diagnosed and who live in conditions of greater social disadvantage. The 
Brazilian polices in HIV/AIDS emphasize that interventions in HIV have to be based on interdisciplinary strategies that consider the phenomenon within a biopsychosocial perspective, and the psychologist should be an integral member of the health team (Perucchi, Rodrigues, Jardim, \& Calais, 2011). However, the Brazilian strategies for PWLH remain primarily focused in medical strategies involving the prevention of mother-tochild HIV transmission (Ministério da Saúde, 2010). In order to broaden these strategies, the present study offers highlights the psychologist can include in the interventions with PWLH, which can contribute to the interdisciplinary practice and to the well-being of these women.

\section{References}

Piccinini, C. A., Carvalho, F. T., Ramos, M. C., Gonçalves, T. R., Lopes, R. C. S., Hugo, C. N., Almeida, S., \& Rossetti, M. L. (2005). Aspectos psicossociais, adesão ao tratamento e saúde da mulher no contexto do HIV/AIDS: Contribuições de um programa de intervenção da gestação ao segundo ano de vida do bebê. Unpublished research project. UFRGS/CEARGS/CDCT.

Bennetts, A., Shaffer, N., Manopaiboon, C., Chaiyakul, P., Siriwasin, W., Mock, P., Klumthanom, K., Sorapipatana, S., Yuvasevee, C., Jalanchavanapate, S., \& Clark, L. (1999). Determinants of depression and HIV-related worry among HIV-positive women who have recently given birth, Bangkok, Thailand. Social Science and Medicine, 49(6), 737-749. doi:1.1016/S0277-9536(99)00108-2

Boletim Epidemiológico AIDS e DST. (2010-2011). Brasília: Ministério da Saúde.

Carvalho, F. T. (2009). Contribuições de uma intervenção psico-educativa para as estratégias de enfrentamento e a qualidade de vida de gestantes portadoras de HIV/AIDS (Unpublished doctoral dissertation). Universidade Federal do Rio Grande do Sul, Porto Alegre, RS.

D’Auria, J. P., Christian, B. J., \& Miles, M. S. (2006). Being there for my baby: Early responses of HIV-infected mothers with an HIV-exposed infant. Journal of Pediatric Health Care, 20(1), 11-18. doi:1.1016/j.pedhc.2005.08.008

Faria, E. R., \& Piccinini, C. A. (2010). Maternidade no contexto do HIV/AIDS: Gestação e terceiro mês de vida do bebê. Estudos de Psicologia (Campinas), 27(2), 147-159. doi:1.1590/S0103-166X2010000200002

Friedland, J., Renwick, R., \& McColl, M. (1996). Coping and social support as determinants of quality of life in HIV/AIDS. AIDS Care, 8(1), 15-31. doi:1.1080/09540129650125966

Gonçalves, T. R. (2011). Maternidade e HIV/AIDS no contexto de uma intervenção psicoeducativa durante a gestação (Unpublished doctoral dissertation). Universidade Federal do Rio Grande do Sul, Porto Alegre, RS.

Gonçalves, T. R., \& Piccinini, C. A. (2008). Experiência da maternidade no contexto do HIV/AIDS aos três meses de vida do bebê. Psicologia: Teoria e Pesquisa, 24(4), 459-47. doi:1.1590/S0102-37722008000400009
Kim, J., Pronyk, P., Barnett, T., \& Watts, C. (2008). Exploring the role of economic empowerment in HIV prevention. AIDS, 22(Suppl. 4), S57-S71. doi:1.1097/01.aids.0000341777.78876.40

Lazarus, R. S., \& Folkman, S. (1984). Stress, appraisal, and coping. New York: Springer.

Leslie, M. B., Stein, J. A., \& Rotheram-Borus, M. J. (2002). The impact of coping strategies, personal relationships, and emotional distress on health-related outcomes of parents living with HIV or AIDS. Journal of Social and Personal Relationships, 19(1), 45-66. doi:1.1177/0265407502191003

Li, L., Lee, S.-J., Thammawijaya, P., Jiraphongsa, C., \& Rotheram-Borus, M. J. (2009). Stigma, social support, and depression among people living with HIV in Thailand. AIDS Care, 21(8), 1007-1013. doi:1.1080/09540120802614358

Ministério da Saúde. Secretaria de Vigilância em Saúde. Departamento de DST, Aids e Hepatites Virais. (2010). Recomendações para profilaxia da transmissão vertical do HIV e terapia anti-retroviral em gestantes. Brasília: Ministério da Saúde.

Moneyham, L., Hennessy, M., Sowell, R., Demi, A., Seals, B., \& Mizuno, Y. (1998). The effectiveness of coping strategies used by HIV-seropositive women. Research in Nursing and Health, 21(4), 351-362. doi:1.1002/ (SICI) 1098-240X(199808)21:4<351::AID-NUR7>3.. $\mathrm{CO} ; 2-\mathrm{E}$

Natividade, J. C., \& Camargo, B. V. (2011). Representações sociais, conhecimento científico e fontes de informação sobre AIDS. Paidéia (Ribeirão Preto), 21(49), 165-174. doi:1.1590/S0103-863X2011000200004

Pakenham, K. I., \& Rinaldis, M. (2001). The role of illness, resources, appraisal, and coping strategies in adjustment to HIV/AIDS: The direct and buffering effects. Journal of Behavioral Medicine, 24(3), 259-279. doi:1.1023/A:1010718823753

Perucchi, J., Rodrigues, F. D., Jardim, L. N., \& Calais, L. B. (2011). Psicologia e políticas públicas em HIV/AIDS: Algumas reflexões. Psicologia \& Sociedade, 23(n ${ }^{\circ}$. esp.), 72-8. doi:1.1590/S0102-71822011000400010

Psaros, C., Geller, P. A., \& Aaron, E. (2009). The importance of identifying and treating depression in HIV infected, pregnant women: A review. Journal of Psychosomatic Obstetrics \& Gynecology, 30(4), 275281. doi:1.3109/01674820903254740

Rice, E., Comulada, S., Green, S., Arnold, E. M., \& Rotheram-Borus, M. J. (2009). Differential disclosure across social network ties among women living with HIV. AIDS and Behavior, 13(6), 1253-1261. doi:1.1007/s10461-009-9554-x

Rocha, N. S., \& Fleck, M. P. A. (2011). Evaluation of quality of life and importance given to spirituality/religiousness/ personal beliefs (SRPB) in adults with and without chronic health conditions. Revista de Psiquiatria Clínica, 38(1), 19-23. doi:1.1590/S0101-60832011000100005 
Rose, M. A., \& Clark-Alexander, B. (1996). Quality of life and coping styles of HIV-positive women with children. Journal of the Association of Nurses in AIDS Care, 7(2), 28-34. doi:1.1016/S1055-3290(96)80011-2

Seidl, E. M. F., \& Tróccoli, B. T. (2006). Desenvolvimento de escala para avaliação do suporte social em HIV/ Aids. Psicologia: Teoria e Pesquisa, 22(3), 317-326. doi:1.1590/S0102-37722006000300008

Seidl, E. M. F., Tróccoli, B. T., \& Zannon, C. M. L. C. (2001). Análise fatorial de uma medida de estratégias de enfrentamento. Psicologia: Teoria e Pesquisa, 17(3), 225-234. doi:1.1590/S0102-37722001000300004

Seidl, E. M. F., Zannon, C. M. L. C., \& Tróccoli, B. T. (2005). Pessoas vivendo com HIV/AIDS: Enfrentamento, suporte social e qualidade de vida. Psicologia: Reflexão e Crítica, 18(2), 188-195. doi:1.1590/S0102-79722005000200006

Silva, M. R., \& Piccinini, C. A. (2007). Sentimentos sobre a paternidade e o envolvimento paterno: Um estudo qualitativo. Estudos de Psicologia (Campinas), 24(4), 561-573. doi:1.1590/S0103-166X2007000400015

Souza, C. L. C., \& Benetti, S. P. C. (2009). Paternidade contemporânea: Levantamento da produção acadêmica no período de 2000 a 2007. Paidéia (Ribeirão Preto), 19(42), 97-106. doi:1.1590/S0103-863X2009000100012

Stern, D. N. (1998). The motherhood constellation: A unified view of parent-infant psychotherapy. London: Karnac.

Zanconato, G., Msolomba, R., Guarenti, L., \& Franchi, M. (2006). Antenatal care in developing countries: The need for a tailored model. Seminars in Fetal \& Neonatal Medicine, 11(1), 15-2. doi:1.1016/j.siny.2005.1.002

Evelise Rigoni de Faria is a Psychologist of the Grupo Hospitalar Conceição.

Tonantzin Ribeiro Gonçalves is a Professor of the Universidade do Vale do Rio dos Sinos.

Fernanda Torres de Carvalho holds a Ph.D. from the Graduate Program in Psychology of the Universidade Federal do Rio Grande do Sul and is a Psychologist of the Secretaria de Saúde do Estado do Rio Grande do Sul.

Rita de Cássia Sobreira Lopes is an Associate Professor of the Instituto de Psicologia of the Universidade Federal do Rio Grande do Sul.

Cesar Augusto Piccinini is an Associate Professor of the Instituto de Psicologia of the Universidade Federal do Rio Grande do Sul.

Received: Dec. $7^{\text {th }}, 2012$

$1^{\text {st }}$ Revision: Jul. 9 ${ }^{\text {th }}, 2013$

Approved: Aug. 10"th 2013
How to cite this article:

Faria, E. R., Gonçalves, T.R., Carvalho, F. T., Lopes, R.C.S., \& Piccinini, C.A. (2014). Coping strategies among Brazilian pregnant women living with HIV. Paidéia (Ribeirão Preto), 24(57),67-74.doi:10.1590/1982-43272457201409 